\title{
Rat Glomerular Mesangial Cells Synthesize Basic Fibroblast Growth Factor Release, Upregulated Synthesis, and Mitogenicity in Mesangial Proliferative Glomerulonephritis
}

\author{
Jürgen Floege, Eudora Eng, Volkard Lindner," Charles E. Alpers, ${ }^{\star}$ \\ Bessie A. Young, Michael A. Reidy, * and Richard J. Johnson \\ Division of Nephrology, Department of Medicine, and *Department of Pathology, \\ University of Washington Medical Center, Seattle, Washington 98195
}

\begin{abstract}
Mesangial injury and cell proliferation are frequent findings in various glomerular diseases in man. Previous studies have demonstrated that basic fibroblast growth factor (bFGF) is a potent mesangial cell mitogen in vitro. To further elucidate the role of bFGF in rat mesangial cell (RMC) proliferation, we examined whether RMC synthesize bFGF in vitro and whether bFGF is involved in mesangial proliferation in vivo. Cultured RMC expressed bFGF protein $(23,21.5$, and $18 \mathrm{kD}$ forms) and bFGF mRNA, and released biologically active bFGF into the culture medium after antibody- and complement-mediated injury. Normal rat glomeruli in vivo contained no detectable bFGF mRNA, but bFGF protein ( 23 and $21.5 \mathrm{kD}$ ) could be demonstrated, which immunolocalized to the mesangium. Glomerular bFGF decreased markedly during the acute phase of glomerulonephritis induced by anti-Thy 1.1 antibody, compatible with mesangial bFGF release after complement-mediated mesangiolysis. During the subsequent mesangial proliferative phase, glomerular bFGF protein and mRNA increased above normal. Intrarenal infusion of heparin did not affect the bFGF immunostaining of glomeruli at this stage, indicating a predominantly intracellular localization of the bFGF. The capability of bFGF to mediate proliferation in the anti-Thy 1.1 model was further supported by experiments in which intravenous bFGF given $24 \mathrm{~h}$ after a subnephritogenic dose of anti-Thy 1.1 antibody led to a 4.9- to 5.1-fold increase in glomerular cell proliferation (with $>60 \%$ of the cells identified as mesangial cells by double immunolabeling). No such increase was observed in normal rats injected with bFGF. These data show that mesangial cells produce and release bFGF after injury and that bFGF is mitogenic for injured mesangial cells in vivo. Release of mesangial cell bFGF thus may be an important mechanism involved in the initiation of mesangial cell proliferation in vivo. (J. Clin. Invest. 90:2362-2369.) Key words: mesangiolysis • cytokine • PDGF • anti-Thy $1.1 \cdot$ heparan sulfate proteoglycan
\end{abstract}

\section{Introduction}

Basic fibroblast growth factor (bFGF) ${ }^{1}$ is expressed by a variety of cells, including fibroblasts, endothelial cells, vascular

Address correspondence and reprint requests to J. Floege, M.D., Division of Nephrology RM-11, University of Washington, Seattle, WA 98195.

Received for publication 11 November 1991 and in revised form 18 June 1992.

J. Clin. Invest.

(c) The American Society for Clinical Investigation, Inc.

$0021-9738 / 92 / 12 / 2362 / 08 \quad \$ 2.00$

Volume 90, December 1992, 2362-2369 smooth muscle cells, and macrophages (reviewed in reference 1). Because of the lack of a signal sequence characteristic of secreted proteins, the mode of cellular bFGF release is unclear. However, lethal cell injury has been shown to liberate intracellular bFGF (reviewed in reference 2). In instances of sublethal cell injury, active bFGF has been shown to be released from its cytosolic storage sites through plasma membrane disruptions (3). Basic FGF is also bound with low affinity to heparan sulfate proteoglycans in extracellular matrices, where it is released by heparin and heparitinases $(4,5)$. A central biological effect of bFGF is the induction of proliferation in various cultured cells, including fibroblasts, endothelial cells, and vascular smooth muscle cells (1). Recent data also emphasize the role of bFGF in the regulation of cell proliferation in vivo, as infusion of bFGF into rats stimulated endothelial and smooth muscle cell proliferation in injured arteries (6) and injection of a neutralizing antibody to bFGF inhibited smooth muscle cell proliferation after vascular injury (7).

Although bFGF has been isolated from whole kidney homogenates (8), to date no studies have addressed either the renal localization of bFGF or a functional role for bFGF in glomerular diseases. However, in vitro experiments performed with the smooth musclelike glomerular mesangial cells have demonstrated the mitogenicity of bFGF for these cells (9). In the present study, we have extended these in vitro observations to the in vivo situation by investigating the anti-Thy 1.1 mesangial proliferative glomerulonephritis model in rats. Anti-Thy 1.1 glomerulonephritis is a well-characterized model (10-14), induced by injection of an anti-mesangial cell antibody (antiThy 1.1) which leads to an acute phase of complement-dependent mesangial cell lysis followed by a phase of intense mesangial cell proliferation (10-12). The relevance of this model for human glomerular diseases is emphasized by the observation that very similar features, namely mesangial cell degeneration or necrosis with disruption of the normal glomerular mesangial architecture and matrix dissolution (mesangiolysis), as well as proliferation of mesangial cells, can be documented in a variety of renal diseases in man, including diabetic nephropathy, acute glomerulonephritis, IgA nephropathy, diffuse lupus nephritis, and renal transplant rejection $(15,16)$. Furthermore, the occurrence of anti-mesangial cell autoantibodies has recently been documented in IgA-nephropathy and Henoch-Schönlein purpura (17).

In the present study, we demonstrate that cultured rat glomerular mesangial cells produce bFGF and release it in re-

1. Abbreviations used in this paper: anti-Thy 1.1, anti-mesangial cell antibody; bFGF, basic fibroblast growth factor; DE6 and DG2, murine monoclonal antibodies against rh-bFGF; PCNA, proliferating cell nuclear antigen; rh-bFGF, recombinant human basic fibroblast growth factor. 
sponse to antibody-mediated mesangial cell injury. We also demonstrate that in the anti-Thy 1.1 glomerulonephritis model glomerular bFGF decreases during the early mesangiolysis, suggesting release, and that bFGF mRNA and protein within glomerular cells increase above normal during the subsequent mesangial proliferative phase. Furthermore, we show that bFGF is mitogenic for mesangial cells both in vitro and in vivo. Thus, bFGF released from damaged mesangial cells may have an important role in the mesangial cell proliferation that occurs in various glomerular diseases.

\section{Methods}

Reagents. Recombinant human bFGF (rh-bFGF) was kindly provided by Synergen, Boulder, CO. Two murine monoclonal $\mathrm{IgG}_{1}$ antibodies against rh-bFGF (DE6 and DG2) were kind gifts of T. Reilly, DuPont-Merck (Wilmington, DE) (18). Affinity-purified polyclonal rabbit anti-rh-bFGF antibody was prepared as described previously (7). Recombinant human acidic FGF was obtained from Upstate Biotechnology Inc. (Lake Placid, NY).

Experiments with cultured rat mesangial cells. Rat mesangial cells were prepared from collagenase-digested glomeruli, as previously described (19). Cells were seeded into six well tissue culture dishes (Corning Glass Works, Corning, NY). After confluency they, were growth arrested for $24 \mathrm{~h}$ in medium (19) containing $0.5 \%$ FCS (Gibco Laboratories, Grand Island, NY). 5\% normal human serum (nonheated or heat-inactivated for $30 \mathrm{~min}$ at $56^{\circ} \mathrm{C}$ ) and $5 \mathrm{mg} / \mathrm{ml}$ anti-Thy $1.1 \mathrm{IgG}$ (14) or normal goat IgG were then added for $4 \mathrm{~h}$, after which the bFGF content in the supernatant was determined by ELISA (see below).

The mitogenicity of rh-bFGF for growth-arrested rat mesangial cells was examined in 24-well tissue culture dishes (Corning Glass Works) in which the cells were incubated for $24 \mathrm{~h}$ with or without bFGF. After $20 \mathrm{~h}, 2.5 \mu \mathrm{Ci}\left[{ }^{3} \mathrm{H}\right.$ ] thymidine (Du Pont-Merck) were added to each well, and the radioactivity incorporated into the cell layer was measured at $24 \mathrm{~h}$ as previously described (20).

The bioactivity of bFGF released from mesangial cells was determined by examining the $\left[{ }^{3} \mathrm{H}\right]$ thymidine incorporation rates into growth arrested, subconfluent (see above) murine Swiss $3 \mathrm{~T} 3$ fibroblasts stimulated with mesangial cell supernatants. The supernatants were preincubated with either $0.5 \mu \mathrm{g}$ DG2 antibody or irrelevant mouse $\mathrm{IgG}_{1}$ per nanogram of bFGF, as previously described (7).

Cellular protein and total RNA were extracted from proliferating, $80-90 \%$ confluent mesangial cells and used for immunoblotting and Northern analysis as described below.

$b F G F$ ELISA. A bFGF ELISA was established using principles described previously (21). Briefly, wells of microtitration plates (Nunc, Roskilde, Denmark) were coated with $0.25 \mu \mathrm{g}$ DE6 anti-bFGF antibody. The wells were blocked with $0.2 \%$ casein (Sigma Chemical Co., St. Louis, MO), and subsequently incubated with the samples followed by $0.8 \mu \mathrm{g} /$ well secondary antibody (an IgG fraction of polyclonal rabbit anti-bFGF [7]). Bound secondary antibody was detected with a biotinylated goat anti-rabbit IgG antibody (1:400, Vector Laboratories, Burlingame, CA), streptavidin-peroxidase (Vector Laboratories, ) and subsequent color development. The detection limit of the ELISA was $0.4 \mathrm{ng} / \mathrm{ml}$ bFGF and no crossreactivity with acidic FGF (up to $1,000 \mathrm{ng} / \mathrm{ml}$ ) was observed.

In vivo model. Anti-Thy 1.1 mesangial proliferative glomerulonephritis was induced in 30 Wistar rats by injection of anti-rat thymocyte plasma $(0.5 \mathrm{ml} / 100 \mathrm{~g}$ body wt i.v. $)(11,14)$. Six additional rats were also complement depleted with cobra venom factor (CVF) (14). In these latter rats, serum $\mathrm{C} 3$ levels, measured by radial immunodiffusion (14), of $<10 \%$ baseline value were maintained throughout the study period. Six normal Wistar rats were studied as controls.

Further in vivo experiments. To analyze the glomerular localization of bFGF, four normal Wistar rats and four Wistar rats at day 5 after the induction of anti-Thy 1.1 nephritis received a bolus infusion of $1,000 \mathrm{U}$ heparin (Elkins-Sinn, Inc., Cherry Hill, NJ) in $0.9 \%$ saline followed by saline only for $15 \mathrm{~min}$ into the right renal artery using previously described techniques (22). Renal biopsies were obtained from the left kidney before the infusion and from the right kidney at $15 \mathrm{~min}$ after the infusion. Biopsies were immunostained for bFGF.

The mitogenicity of recombinant human bFGF for glomerular cells in vivo was examined in normal Wistar rats, as well as in Wistar rats that had received a subnephritogenic dose of anti-rat thymocyte plasma $(0.1 \mathrm{ml} / 100 \mathrm{~g}$ body wt $)$ at 24 hours before the experiment. The rats received a bolus injection of either $40 \mu \mathrm{g}$ bFGF or vehicle $(0.3 \mathrm{M}$ glycerin in $10 \mathrm{mM}$ PBS, $\mathrm{pH} 7.4$ ) into a tail vein and renal biopsies were obtained on days 1, 2, and 4 after the injection and immunostained for proliferating cells (see below).

Renal morphology and immunohistochemistry. Renal biopsies were fixed in methyl Carnoy's solution (11) and embedded in paraffin. Mesangiolysis was graded semiquantitatively in periodic acid-Schiffstained sections on a scale from $0-4+$ as previously described (12). Immunoperoxidase staining was performed as described previously (11) using the following primary antibodies: DE6 or DG2 (bFGF); 19A2 (American Biotech Inc., Plantation, FL), a murine IgM monoclonal antibody against the proliferating cell nuclear antigen (PCNA) (11); and ED1 (Bioproducts for Science, Inc., Indianapolis, IN), a murine monoclonal $\operatorname{lgG}_{1}$ antibody to monocytes and macrophages. Additionally, glomerular bFGF expression was examined on $4-\mu \mathrm{m} \mathrm{sec}-$ tions of frozen, ethanol/ether-fixed kidney tissue (13) using a polyclonal anti-bFGF antibody (7). Negative controls consisted of substitution of the primary antibody with equivalent concentrations of an irrelevant murine monoclonal antibody or normal rabbit IgG. For each biopsy, $>20$ cross sections of glomeruli containing $>20$ discrete capillary segments each were evaluated by an observer, who was unaware of the origin of the slides. Glomerular bFGF expression was graded semiquantitatively, based on the extent of mesangial staining, as $0-5 \%$ (grade 0 ); $5-25 \%$ (I), $25-50 \%$ (II), $50-75 \%$ (III), or $>75 \%$ (IV) of the glomerular tuft showing positive staining (13).

Double immunostaining was performed as reported previously (12) by first staining the sections for PCNA, followed by staining for either bFGF (DE6) or mesangial cells (OX-7, a murine monoclonal anti-Thy 1.1; Accurate Chem. \& Sci. Corp., Westbury, NY). Negative controls consisted of omission of either of the primary antibodies.

Immunoblotting of $b F G F$. Cultured mesangial cells and isolated glomeruli (11) were lysed as described (7). The samples were reduced with $50 \mathrm{mM}$ DTT (Sigma Chemical Co.) and electrophoresed through a 5\% stacking, $12.5 \%$ separating SDS-PAGE gel (21). The lanes were loaded with either $150 \mu \mathrm{g}$ of protein extracted from cultured cells, or the protein extracted from 1,500 glomeruli (as determined by counting the isolated glomeruli before lysis). The electrophoresed proteins were transferred to nitrocellulose filters by electroblotting and were immunostained (21) with the DE6 or DG2 antibody or an irrevelevant monoclonal antibody as primary antibodies.

Preparation of RNA and Northern analysis. Total RNA was extracted from cultured cells or from three separate glomerular preparations (11) using RNAzol $\mathbf{B}^{\mathrm{R}}$ (Cinna/Biotecx Laboratories, Friendswood, TX) followed by a $\mathrm{LiCl}$ precipitation as described previously (23). Northern analysis was performed as described (12) using $30 \mu \mathrm{g}$ of denatured RNA per lane. A 539-bp, radiolabeled (12) X HOI/NCO1 fragment of rat ovarian bFGF cDNA from plasmid RObFGF-477 (24) (a kind gift of A. Baird, Whittier Institute, La Jolla, CA) was used to detect rat bFGF transcripts. Murine NIH 3T3 cells, transfected with human bFGF cDNA (ZIP-cells, a kind gift of R. Florkiewicz, Whittier Institute, La Jolla, CA ) (25), expressing 6.0- and 8.8-kb bFGF mRNA transcripts, served as a positive control. Membranes were prehybridized and hybridized as described and autoradiograms were obtained (14).

Statistical analysis. All values are expressed as mean \pm SD. Statistical significance (defined as $P<0.05$ ) was evaluated using the Student's $t$ test or one way analysis of variance with modified $t$ tests performed using the Bonferroni correction. 


\section{Results}

Mesangial cells in culture proliferate in response to $b F G F$ and express $b F G F$ protein and $m R N A$. After $24 \mathrm{~h}$ incubation, rhbFGF stimulated the $\left[{ }^{3} \mathrm{H}\right]$ thymidine incorporation rate in rat mesangial cells $1.8 \pm 0.3$-fold ( $10 \mathrm{ng} / \mathrm{ml}$ bFGF; $n=4)$ or $2.4 \pm 0.4$-fold ( $50 \mathrm{ng} / \mathrm{ml} \mathrm{bFGF;} n=4$ ) over that observed in nonstimulated cells.

Immunofluorescent staining of methanol-fixed, subconfluent mesangial cells revealed bFGF in a granular pattern in the cytoplasm (Fig. 1). Immunoblotting using either the DE6 (Fig. 2) or DG2 antibody demonstrated the presence of 23-, 21.5-, and 18.0-kD bFGF forms in mesangial cell lysates. Furthermore, 6.8 -kb bFGF mRNA transcripts were present in total mesangial cell RNA (Fig. 3).

Anti-mesangial cell antibody and complement induce release of biologically active bFGF from mesangial cells. The mesangial cell release of bFGF was investigated in growtharrested cells that had been injured with $5 \mathrm{mg} / \mathrm{ml}$ anti-Thy 1.1 IgG and 5\% normal human serum as a complement source. In preliminary experiments, we had observed that these concentrations of antibody and complement resulted in lethal cell injury, as judged by cellular release of ${ }^{51} \mathrm{Cr}$ (data not shown). In the supernatant of lethally injured mesangial cells, bFGF concentrations increased from nondetectable levels at the start of the experiment to $1.58 \pm 0.67 \mathrm{ng} / \mathrm{ml}(n=5)$ after $4 \mathrm{~h}$. This increase in the extracellular bFGF concentration appeared to reflect cellular release of preformed bFGF rather than increased synthesis, since immunofluorescent staining of the cells after $4 \mathrm{~h}$ of stimulation with anti-Thy 1.1 antibody and complement showed an almost complete loss of cellular bFGF staining (data not shown). Basic FGF levels in the cell supernatant remained below the ELISA detection threshold ( $<0.4 \mathrm{ng} /$ $\mathrm{ml}$ ) after $4 \mathrm{~h}$ of incubation with either normal goat IgG plus complement, anti-Thy 1.1 antibody plus heat-inactivated complement or with a nonlytic concentration of anti-Thy 1.1 plus complement ( $n=3$ each). Furthermore, no bFGF was detectable in supernatants of actively proliferating, nonmanipulated cells at 24 or $72 \mathrm{~h}$ after changing the medium $(n=5)$.

To determine the bioactivity of mesangial cell bFGF, murine Swiss $3 \mathrm{~T} 3$ fibroblasts, which are growth responsive to bFGF (Table I), were incubated with mesangial cell superna-

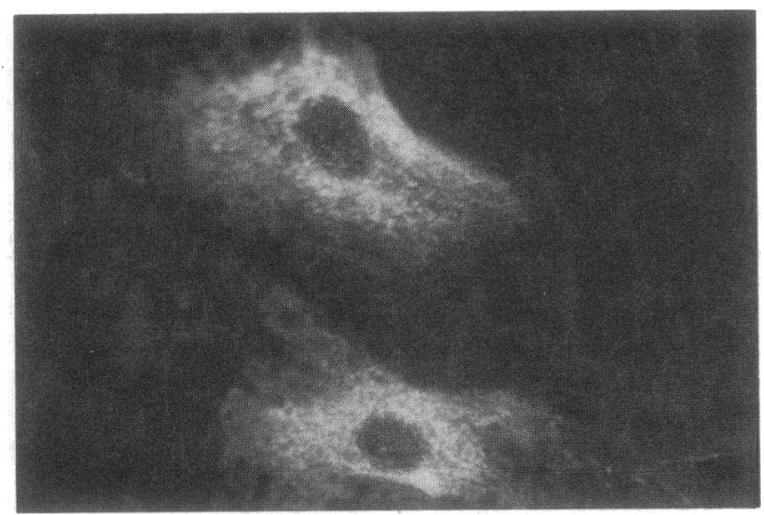

Figure 1. Immunofluorescent staining of rat mesangial cells with the DE6 anti-bFGF antibody. Positive cytoplasmic staining in a granular pattern is present. $\times 400$.

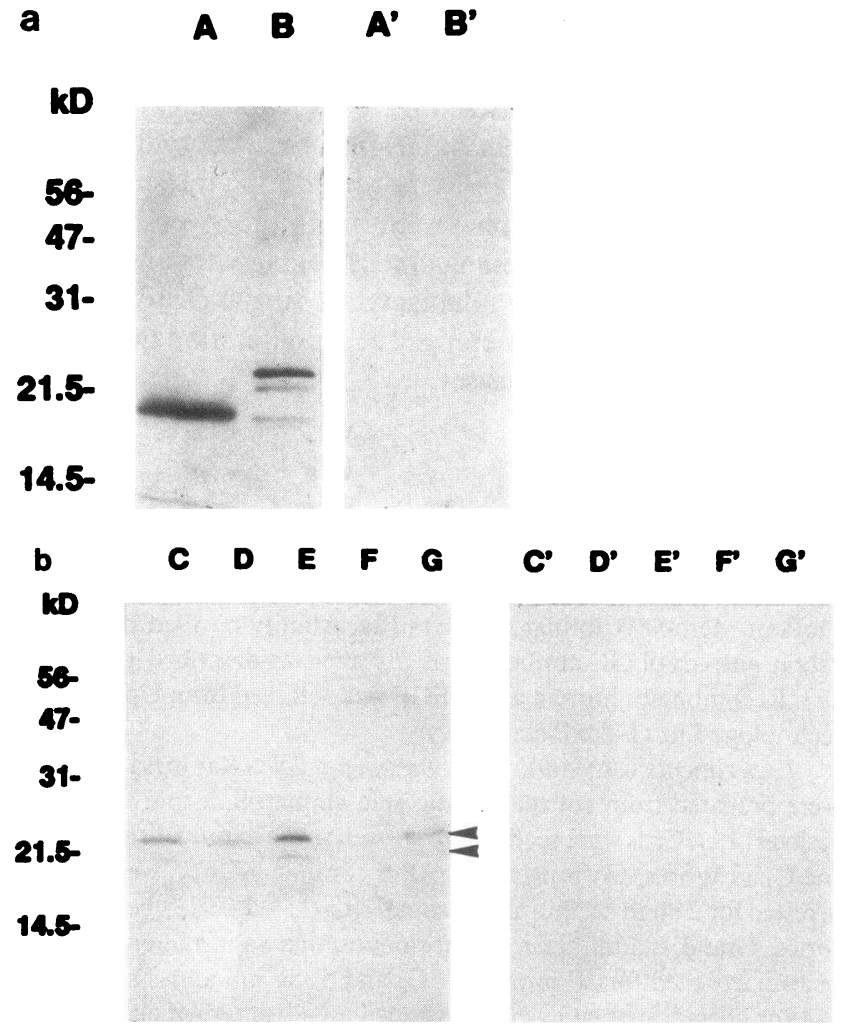

Figure 2. Immunoblotting for bFGF using the monoclonal DE6 antibFGF antibody (lanes $A-G$ ) or an irrelevant murine monoclonal antibody (lanes $A^{\prime}-G^{\prime}$ ) in lysates of cultured glomerular cells or lysates of isolated glomeruli. Lanes $A$ and $A^{\prime}$, recombinant human bFGF; lanes $B$ and $B^{\prime}$, cultured rat mesangial cells; lanes $C$ and $C^{\prime}$, glomeruli of rats on day 6 after disease induction; lanes $D$ and $D^{\prime}$, glomeruli of rats on day 4 after disease induction; lanes $E$ and $E^{\prime}$, glomeruli of complement depleted rats on day 4 after disease induction; lanes $F$ and $F^{\prime}$, glomeruli of rats on day 1 after disease induction; lanes $G$ and $G^{\prime}$; normal rat glomeruli. 23-, 21.5-, and 18-kD bFGF bands are present in mesangial cell extracts. The same $23-$ and $21.5-\mathrm{kD}$ bands (arrows) are detectable in normal rat glomeruli, and are decreased on day 1 and increased on days 4 and 6 after induction of anti-Thy 1.1 glomerulonephritis. Complement depletion before disease induction abolishes the increase in bFGF expression on day 4. One representative experiment is shown.

tants. Supernatants of mesangial cells injured with anti-Thy 1.1 antibody plus complement induced a 5.6-fold increase of the 3T3-fibroblast proliferation rate (Table I). However, in contrast to the mitogenic effect of recombinant human bFGF, which was reduced by $>70 \%$ by preincubation with a neutralizing anti-bFGF antibody (DG2), only a partial, though significant, reduction $(-12.2 \pm 5.9 \% ; P=0.015)$ was noted when the mesangial cell supernatants were preincubated with the DG2 antibody (Table I). This finding may result from the fact that the neutralizing capacity of the DG2 antibody is markedly reduced in the presence of heparan sulfate proteoglycans ( $\mathrm{V}$. Lindner, unpublished observations), which are likely to be coreleased from injured mesangial cells. Alternatively the neutralizing capacity of the DG2 antibody may not be comparable for recombinant human and naturally occurring rat bFGF, and/ or mesangial cell lysis may lead to the concomitant release of other mitogens for $3 \mathrm{~T} 3$ fibroblasts in addition to bFGF. Fi- 


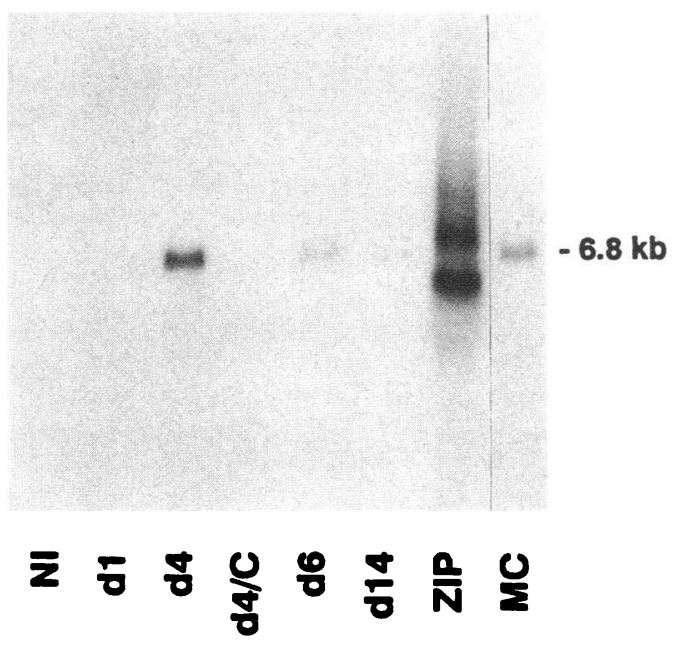

Figure 3. Northern analysis of total glomerular RNA obtained from normal rats, rats with anti-Thy 1.1 glomerulonephritis (ATS) on days $1,4,6,14$, complement-depleted rats with anti-Thy 1.1 glomerulonephritis on day 4 (d4/CVF), ZIP cells (positive control; 6.0- and 8.8-kb transcripts), and rat mesangial cells $(M C)$ for the expression of bFGF mRNA. One of three experiments is shown.

nally, anti-Thy $1.1 \mathrm{IgG}$ and complement themselves may affect the proliferation of growth arrested 3T3 fibroblasts. This latter assumption received support from the observation that incubation of 3T3 fibroblasts with anti-Thy $1.1 \mathrm{IgG}$ and complement, which both had been preincubated at $37^{\circ} \mathrm{C}$ for $4 \mathrm{~h}$ in the absence of any cells, also induced a significant increase in the fibroblast proliferation rate ( Table I). No influence of previous incubation of the anti-Thy $1.1 \mathrm{IgG}$ with anti-bFGF antibody was noted under these circumstances (Table I).

When 3T3 fibroblasts were incubated with supernatants of mesangial cells that had been stimulated with anti-Thy 1.1 an-

Table I. Mitogenicity of bFGF or Rat Mesangial Cell Supernatants for Cultured Swiss $3 T 3$ Fibroblasts

\begin{tabular}{|c|c|c|}
\hline \multirow[b]{2}{*}{ Stimulus } & \multicolumn{2}{|c|}{$\begin{array}{l}\text { Increase of the }\left[{ }^{3} \mathrm{H}\right] \text { thymidine incorporation rate } \\
\text { in 3T3-fibroblasts after preincubation } \\
\text { of the stimulus with }\end{array}$} \\
\hline & Irrelevant murine $\operatorname{lgG}_{1}{ }^{\ddagger}$ & Anti-bFGF (DG2) \\
\hline $1 \mathrm{ng} / \mathrm{ml} \mathrm{bFGF}$ & $4.7 \pm 1.5$ & $1.3 \pm 0.5^{*}$ \\
\hline $10 \mathrm{ng} / \mathrm{ml} \mathrm{bFGF}$ & $5.2 \pm 1.6$ & $1.4 \pm 0.3^{*}$ \\
\hline MC-supernatant $A^{\S}$ & $2.8 \pm 1.6$ & $3.2 \pm 1.9$ \\
\hline MC-supernatant B & $5.6 \pm 1.0$ & $4.9 \pm 0.7^{*}$ \\
\hline $\begin{array}{l}\text { Anti-Thy } 1.1 \text { and } \\
\text { complement }\end{array}$ & $1.9 \pm 0.6$ & $1.9 \pm 0.8$ \\
\hline
\end{tabular}

Baseline 4-h $\left[{ }^{3} \mathrm{H}\right]$ thymidine incorporation rates were $22,957 \pm 3,521$ $\operatorname{cpm}(n=5)$. Data are mean \pm SD of five experiments. ${ }^{*} P<0.05$ vs samples incubated with irrelevant murine IgG (paired Student's $t$ test). ${ }^{\ddagger} 0.5 \mu \mathrm{g}$ antibody/ng of bFGF. ${ }^{\S}$ Supernatants of rat mesangial cells that had been stimulated with anti-Thy 1.1 antibody and heatinactivated complement for $4 \mathrm{~h}$ (bFGF content $<0.4 \mathrm{ng} / \mathrm{ml}$ ). " Supernatants of rats mesangial cells that had been stimulated with anti-Thy 1.1 antibody and complement for $4 \mathrm{~h}$ (bFGF content $1.58 \pm 0.67 \mathrm{ng} / \mathrm{ml}$ ). 'Anti-Thy 1.1 antibody and complement that had been incubated for $4 \mathrm{~h}$ at $37^{\circ} \mathrm{C}$ in the absence of mesangial cells. tibody and heat-inactivated complement, no reduction of the fibroblast proliferation rate was observed after preincubation of the supernatant with the anti-bFGF antibody (Table I).

$b F G F$ is expressed in glomeruli of normal rats. Positive bFGF immunostaining using the DE6 (Fig. $4 A$ ) or DG2 antibFGF antibodies was observed in the mesangium of normal rat glomeruli. Staining of other glomerular cells was weak or absent. No staining of the glomerular basement membrane, using either an immunoperoxidase (Fig. $4 A$ ) or immunofluorescence procedure, was apparent. Positive glomerular bFGF staining was also observed when frozen kidney sections were stained with the polyclonal anti-bFGF antibody (data not shown ). However, in this case, the less well-preserved morphology prevented the localization of the staining to specific glomerular substructures. Intrarenal infusion of heparin into normal rats did not affect the glomerular bFGF staining pattern to a detectable degree ( $n=4$; data not shown $)$, suggesting that the majority of the glomerular bFGF was located intracellularly (26). Apart from the glomerular tuft, bFGF immunostaining using the DE6 antibody in the renal cortex was positive in the glomerular capsule, the wall of blood vessels, the interstitium, distal tubules, and collecting ducts.

Immunoblotting using either the DE6 (Fig. 2) or DG2 antibFGF antibody confirmed the presence of a $23-$ and $21.5-\mathrm{kD}$ bFGF form in lysates of normal rat glomeruli. No clear $18-\mathrm{kD}$ band could be demonstrated.

bFGF mRNA transcripts were not detectable in total glomerular RNA isolated from normal rats (Fig. 3).

Basic characteristics of the mesangioproliferative glomerulonephritis model. The injection of anti-Thy 1.1 antibody into rats resulted in acute mesangiolysis on days 1 and 2 (Table II). Significant glomerular cell proliferation was observed between days 2 and 6 (Table II). Double immunostaining of biopsies obtained on days 2,4 , and 6 ( Table III) showed that at any time point, the majority of proliferating glomerular cells also stained with a mesangial cell marker (anti-Thy 1.1), which was in contrast to normal glomeruli, where the majority of proliferating cells were nonmesangial (presumably endothelial cells (27)). On day 14 , glomerular cell proliferation had returned to the normal range (Table II), although many glomeruli still exhibited hypercellularity and mesangial matrix expansion. Marked glomerular monocyte/macrophage infiltration was noted on day 1 , after which it decreased, but still remained elevated in comparison with normal rats on days 2,4 , and 6 (Table II). Complement depletion before disease induction abolished all aforementioned pathological changes on day 4 (Table II).

Glomerular bFGF expression during mesangioproliferative glomerulonephritis. Fig. $4 B$ and Table II show that the glomerular area immunostaining for bFGF using either the monoclonal DE6 antibody or a polyclonal anti-bFGF antibody decreased concurrently with the mesangiolysis on days 1 and 2 after disease induction. At all later stages, the glomerular area staining for bFGF was significantly increased in comparison with normal glomeruli (Fig. $4 C$ and Table II). Areas of increased bFGF staining frequently corresponded to areas of hypercellularity (Fig. $4 C$ ). Double immunostaining for proliferating cells (PCNA-positive) and bFGF showed that the majority of proliferating cells also stained positive for bFGF on day 4 (78 $\pm 6 \%$ of glomerular PCNA-positive cells) and day 6 $(76 \pm 5 \%)$. In contrast, immunostaining of $2-\mu \mathrm{m}$ serial sections for bFGF and monocytes/macrophages (ED1) failed to reveal 

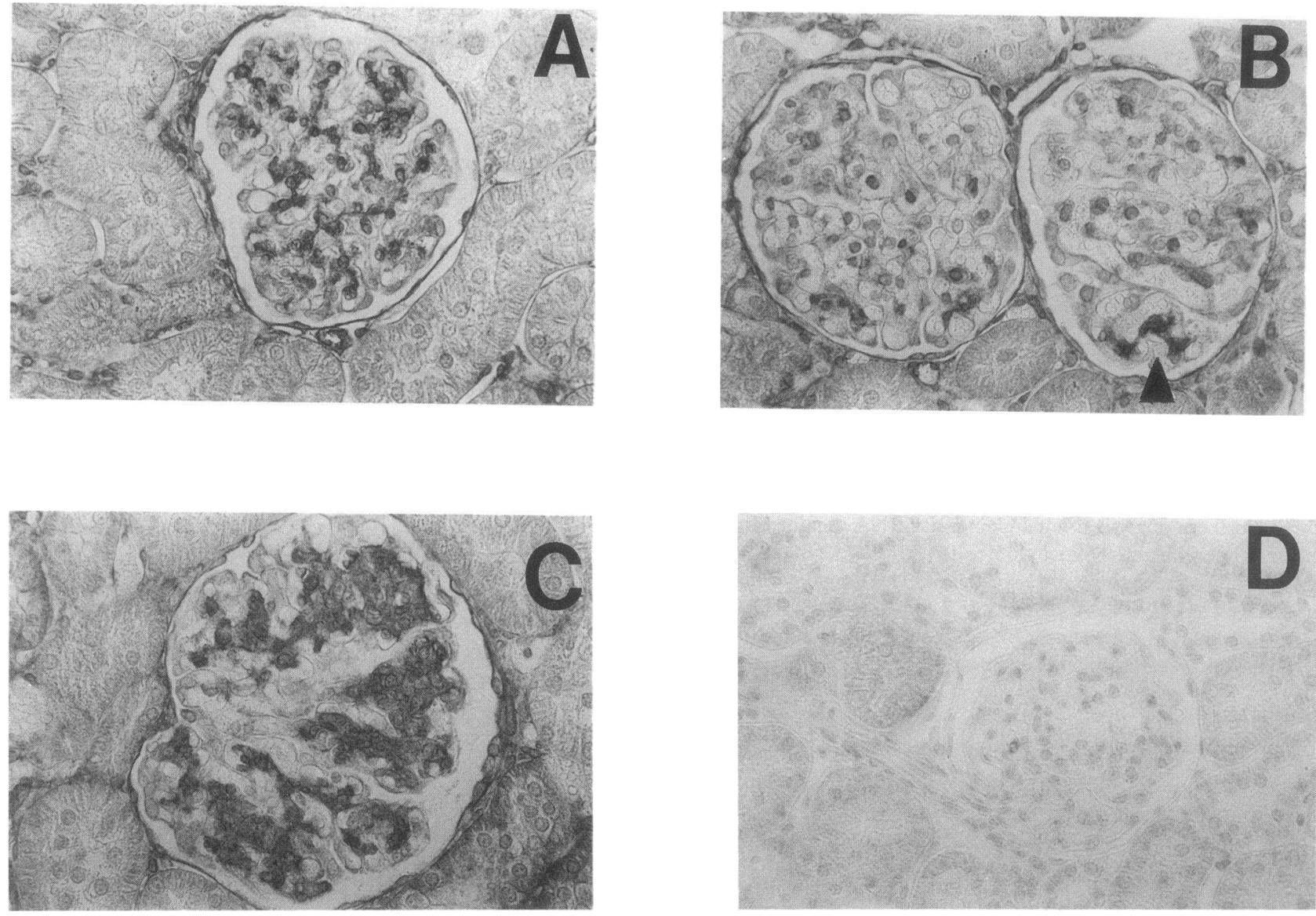

Figure 4. Glomerular immunostaining for bFGF using the monoclonal DE6 anti-bFGF antibody in a $(A)$ normal rat, $(B)$ a rat with anti-Thy 1.1 mesangioproliferative glomerulonephritis on day 1 , and $(C)$ on day 6 . Focal glomerular bFGF staining in a mesangial pattern is present in the normal rat. Only rare areas of focal glomerular staining (arrow) remain on day 1 after disease induction, while the staining markedly increases on day 6 after disease induction. No glomerular staining of normal kidney tissue is observed when the DE6 antibody is replaced by an irrelevant murine monoclonal antibody $(D)$. Immunoperoxidase with methyl green counterstain. $\times 400$.

a colocalization of bFGF and the ED1 antigen (data not shown).

As in normal rats, intrarenal infusion of heparin into rats with anti-Thy 1.1 nephritis on day 5 did not affect the glomeru- lar bFGF staining pattern to a detectable degree $(n=4$; data not shown).

Immunoblotting using either the DE6 (Fig. 2) or DG2 antibFGF antibody confirmed the decrease of the glomerular

Table II. Comparison of Mesangiolysis, Glomerular Proliferating Cells, Glomerular Monocyte/Macrophages and Glomerular bFGF Stain in Normal Rats Day 0, Rats with Anti-Thy 1.1 Mesangioproliferative Glomerulonephritis on Days 1, 2, 4, 6, and 14, and Complement-Depleted Rats (CVF) with Anti-Thy 1.1 Glomerulonephritis on Day 4

\begin{tabular}{|c|c|c|c|c|c|}
\hline Day & $\begin{array}{c}\text { Glomerular bFGF } \\
\text { expression } \\
\text { (score) } \\
\text { DE6-stain }^{\ddagger}\end{array}$ & $\begin{array}{l}\text { Glomerular bFGF } \\
\text { expression } \\
\text { (score) } \\
\text { polyclonal } \\
\text { antibody } \\
\text { stain }^{8}\end{array}$ & $\begin{array}{l}\text { Mesangiolysis } \\
\text { score }\end{array}$ & $\begin{array}{l}\text { Proliferating } \\
(\text { PCNA+) cells } \\
\text { per glomerular } \\
\text { cross section }\end{array}$ & $\begin{array}{c}\text { Monocyte/ } \\
\text { macrophages } \\
\text { per glomerular } \\
\text { cross section }\end{array}$ \\
\hline 0 & $1.4 \pm 0.1$ & $1.3 \pm 0.1$ & $0 \pm 0$ & $0.6 \pm 0.5$ & $2.5 \pm 0.8$ \\
\hline 1 & $0.3 \pm 0.2^{*}$ & $0.3 \pm 0.4^{*}$ & $2.7 \pm 0.5^{*}$ & $1.9 \pm 0.7^{*}$ & $20.0 \pm 3.0^{*}$ \\
\hline 2 & $0.6 \pm 0.2^{*}$ & $0.2 \pm 0.1^{*}$ & $2.8 \pm 0.4^{*}$ & $9.9 \pm 1.5^{*}$ & $14.9 \pm 3.3^{*}$ \\
\hline 4 & $2.1 \pm 0.2^{*}$ & $1.7 \pm 0.4$ & $1.5 \pm 0.5^{*}$ & $19.4 \pm 1.3^{*}$ & $9.5 \pm 2.0^{*}$ \\
\hline 6 & $2.6 \pm 0.5^{*}$ & $1.8 \pm 0.3$ & $1.0 \pm 0.6^{*}$ & $11.4 \pm 4.7^{*}$ & $9.9 \pm 2.5^{*}$ \\
\hline 14 & $2.2 \pm 0.1^{*}$ & $2.4 \pm 0.2^{*}$ & $0 \pm 0$ & $0.6 \pm 0.4$ & $3.8 \pm 0.9$ \\
\hline $4 / \mathrm{CVF}$ & $1.3 \pm 0.1$ & $1.5 \pm 0.4$ & $0 \pm 0$ & $0.8 \pm 0.4$ & $3.0 \pm 0.8$ \\
\hline
\end{tabular}

Data are mean \pm SD. $n=6$ each. ${ }^{*} P<0.05$ vs day 0 . ${ }^{*}$ Staining of methyl Carnoy's fixed paraffin-embedded section with the monoclonal anti-bFGF antibody DE6. ${ }^{\S}$ Staining of ether/ethanol fixed cryostat sections with an affinity purified, polyclonal anti-bFGF antibody. 
Table III. Identification of Proliferating Glomerular Cells in Normal Rat Glomeruli Day 0 and during Anti-Thy 1.1 Nephritis by Double Immunostaining for PCNA and the Anti-Thy 1.1 Antigen Present on the Mesangial Cell Surface

\begin{tabular}{cccc}
\hline & \multicolumn{2}{c}{ Percentage of cells per glomerular cross section* } \\
\cline { 2 - 4 } $\begin{array}{c}\text { Day after } \\
\text { disease } \\
\text { induction }\end{array}$ & $\begin{array}{c}\text { Proliferating, } \\
\text { mesangial } \\
\text { (PCNA+, Thy 1+) }\end{array}$ & $\begin{array}{c}\text { Proliferating, } \\
\text { nonmesangial } \\
\text { (PCNA+, Thy 1-) }\end{array}$ & Not classifiable \\
\hline 0 & $31 \pm 6 \%$ & $51 \pm 8 \%$ & $18 \pm 4 \%$ \\
2 & $71 \pm 3 \%$ & $22 \pm 3 \%$ & $6 \pm 2 \%$ \\
4 & $84 \pm 5 \%$ & $7 \pm 1 \%$ & $9 \pm 2 \%$ \\
6 & $82 \pm 4 \%$ & $8 \pm 2 \%$ & $11 \pm 2 \%$ \\
\hline
\end{tabular}

* Cells were identified as proliferating mesangial cells if they showed positive nuclear staining for PCNA and if the nucleus was completely surrounded by cell membrane positive for OX-7 (anti-Thy 1.1). Proliferating cells in which the PCNA positive nucleus did not border on a cell membrane positive for OX-7 were classified as nonmesangial. Proliferating (PCNA+) cells that could not be clearly identified as $\mathrm{OX}-7$ positive or negative were considered nonclassifiable.

bFGF content on day 1 with a subsequent increase of 21.5 - and 23-kD bFGF at days 4 and 6 . Immunoblotting also suggested the appearance of a very weak $18-\mathrm{kD}$ bFGF band at these latter time points (Fig. 2).

Whereas bFGF mRNA transcripts could not be demonstrated in glomerular RNA extracted from normal rats or from rats on day 1 after disease induction by Northern analysis, a 6.8-kb transcript was identified in glomerular RNA from rats on 4,6 , and $14 \mathrm{~d}$ after anti-Thy 1.1 antibody injection (Fig. 3).

Complement depletion before disease induction prevented the increase in bFGF mRNA and protein expression on day 4 (Figs. 2 and 3, and Table II).

bFGF is mitogenic for glomerular cells in vivo. In normal rats, glomerular cell proliferation remained in the normal range (0.4-0.9 PCNA-positive nuclei per glomerular cross section) at 1,2 or 4 days after an injection of $40 \mu \mathrm{g}$ i.v. bFGF or vehicle (Table IV). In contrast, if rats received a subnephritogenic dose of anti-Thy 1.1 antibody followed $24 \mathrm{~h}$ later by $40 \mu \mathrm{g}$ bFGF, the number of proliferating glomerular cells increased

Table IV. Mitogenicity of Intravenously Injected bFGF for Glomerular Cells in Normal Wistar Rats or in Wistar Rats at 24 h after Injection of a Subnephritogenic Dose of Anti-Thy 1.1 Antibody

\begin{tabular}{lcccc}
\hline & & $\begin{array}{c}\text { Time after } \\
\text { injection of } \\
\text { vehicle or } \\
\text { bFGF }\end{array}$ & \multicolumn{2}{c}{$\begin{array}{c}\text { PCNA-positive nuclei per } \\
\text { glomerular cross section } \\
\text { in rats infused with }\end{array}$} \\
\hline Vehiclet & bFGF $^{\ddagger}$ \\
Normal rats & $n$ & $d$ & & \\
Subnephritogenic & 3 & 1 & $0.6 \pm 0.2$ & $0.7 \pm 0.1$ \\
Anti-Thy 1.1 dose & 3 & 2 & $0.6 \pm 0.1$ & $0.5 \pm 0.2$ \\
& 5 & 1 & $1.4 \pm 0.2$ & $6.8 \pm 1.2^{*}$ \\
& 3 & 2 & $0.6 \pm 0.2$ & $3.9 \pm 0.5^{*}$ \\
& & 4 & $0.6 \pm 0.2$ & $0.9 \pm 0.4$
\end{tabular}

Data are mean \pm SD. ${ }^{*} P<0.01$ vs vehicle infused rats. ${ }^{\ddagger} 10 \mathrm{mM}$ PBS, $0.3 \mathrm{M}$ glycerine. ${ }^{\S} 40 \mu \mathrm{g}$ recombinant human $\mathrm{bFGF}$ in vehicle. 4.9-fold on day 1 and 5.1-fold on day 2, as compared to vehicle injected controls (Table IV). On day 4 after the bFGF injection, glomerular cell proliferation had returned to the normal range again ( Table IV). Double immunostaining of renal biopsies from rats that had received anti-Thy 1.1 antibody plus bFGF showed that most of the proliferating glomerular cells stained with a mesangial cell marker (anti-Thy $1.1 ; 63 \pm 10 \%$ on day 1 and $57 \pm 9 \%$ on day 2), but not with a monocyte/macrophage marker (ED1; $<3 \%$ on days 1 and 2$) .22 \pm 11 \%(24 \mathrm{~h})$ and $23 \pm 4 \%(48 \mathrm{~h})$ of the proliferating glomerular cells were identified as nonmesangial cells, while the remainder could not be classified with certainty as either mesangial or nonmesangial.

\section{Discussion}

In agreement with previous findings of Silver et al (9), who showed that exposure of cultured mesangial cells to bFGF ( 10 $\mathrm{ng} / \mathrm{ml}$ ) induced a 4-5-fold increase in their $\left[{ }^{3} \mathrm{H}\right]$ thymidine incorporation rate, the present study confirms that cultured mesangial cells proliferate in response to exogenous bFGF. Both studies thus indicate the presence of bFGF receptors on rat mesangial cells. In addition to high affinity bFGF receptors, heparan sulfate proteoglycans, especially syndecan, are an essential requirement for the binding of bFGF to its cellular receptor $(28,29)$. Of relevance, cultured mesangial cells have been shown to produce heparan sulfate proteoglycans (30).

Our study shows that in addition to responding to bFGF, mesangial cells also express bFGF mRNA and synthesize various bFGF forms with apparent relative molecular masses of $18,21.5$, and $23 \mathrm{kD}$. Similar bFGF forms have been detected in other tissues or cultured cells and are believed to originate from alternate usage of translation initiation codons (31). The nondetectable levels of bFGF in the culture medium of nonstimulated, growth arrested or actively proliferating mesangial cells is likely to reflect the lack of a signal peptide, indicative of secreted proteins, in the bFGF molecule (32). In preliminary experiments, we have also been unable to detect cellular release of bFGF after stimulating serum-starved mesangial cells for 24 $h$ with various agonists, including platelet-derived growth factor, tumor necrosis factor- $\alpha$, IL-1 $\beta$, IL-6, transforming growth factor- $\beta$, lipopolysaccharide, or FCS (J. Floege, unpublished observations). In contrast to these various conditions, mesangial cell release of biologically active bFGF into the culture medium was noted upon lethal mesangial cell injury with antiThy 1.1 antibody and complement. The data presented in Table I suggest that bFGF was one of the fibroblast mitogens released from the injured mesangial cells.

Isoforms of bFGF similar to those detected in cultured rat mesangial cells were found in glomerular lysates of normal rats. In agreement with findings in a variety of other tissues (24), bFGF mRNA levels in normal glomerular RNA were below the limits of detection, supporting the notion (24) that the presence of bFGF protein in glomeruli is predominantly caused by storage and not continuous gene expression. Analogous to the in vitro situation, antibody-mediated mesangiolysis in vivo led to an almost complete loss of glomerular bFGF staining, suggesting release of bFGF during the complementmediated mesangial cell lysis in vivo. After its cellular release, bFGF may enter the circulation, from which it is rapidly cleared (33), or it may bind to either the glomerular extracellular matrix $(4,5)$ or neighboring glomerular cells expressing 
bFGF receptors. However, binding of bFGF to the glomerular extracellular matrix during the early stages of anti-Thy 1.1 nephritis appears unlikely, since the mesangial matrix at this time is severely disrupted and heparan sulfate proteoglycan staining decreased (13). Binding of released bFGF to cells has been shown to result in fast bFGF removal, since bound bFGF is rapidly internalized, followed by intracellular degradation (34). This latter observation in particular may explain how released bFGF can exert significant biological effects, such as induction of growth, despite an almost complete loss of bFGF from the injured tissue as observed in early anti-Thy 1.1 nephritis.

After the initial mesangiolysis, marked proliferation of mesangial cells ensues in the anti-Thy 1.1 glomerulonephritis (this study and reference 12). Our data show that this proliferative response was associated with increased glomerular synthesis of bFGF. These findings strongly suggest that the glomerular bFGF in normal and diseased rats is largely derived from mesangial cells. However, we cannot exclude the presence of low amounts of bFGF, especially in glomerular endothelial cells, since endothelial cells of different origin have been shown to synthesize bFGF $(35,36)$. Despite a report on the presence of bFGF in peritoneal macrophages (37), glomerular monocytes/macrophages do not appear to contribute significantly to the glomerular bFGF, since during the marked macrophage infiltration on day 1 after disease induction, glomerular bFGF became nearly undetectable and no bFGF immunostaining of monocytes/macrophages was observed.

In addition to the presence of bFGF in glomerular mesangial cells, observations in other tissues have shown that subsequent to its cellular release, bFGF binds to and is probably stored by heparan sulfate molecules in the extracellular matrix. Biologically active bFGF can then be released from the matrix by either heparin or heparan sulfate-degrading enzymes $(4,5)$. However, two observations of the present study suggest that no or very low amounts of bFGF are present in the glomerular extracellular matrix. First, no evidence for binding of bFGF to the abundant heparan sulfate proteoglycans in the glomerular basement membrane (13) was apparent in normal or diseased rats. Secondly, intrarenal infusion of large doses of heparin, which have been shown to release tissue-bound bFGF into the circulation (26), did not affect the immunostaining for bFGF in normal glomeruli or glomeruli on day 5 of anti-Thy 1.1 nephritis, in which the extracellular matrix is markedly expanded (13).

Cellular release of bFGF after the injection of antimesangial cell antibody (anti-Thy 1.1) may play an important role in the regulation of mesangial cell proliferation. The mitogenic effect of bFGF on mesangial cells could be a direct effect or it could be mediated by bFGF-induced synthesis of PDGF (9). In the mesangioproliferative phase of the anti-Thy 1.1 model (days 3 and 5), but not in the early mesangiolytic phase (day 1), we have previously demonstrated under the same conditions as in this study an upregulation of glomerular PDGF expression (14), which immunohistochemically and by in situ hybridization localized to mesangial cells (38). Interestingly, however, administration of a neutralizing anti-PDGF antibody in vivo did not block the initial (day 2 ) glomerular cell proliferation, but only affected the proliferation rate on day 4 (39). The present study suggests that the initial nonresponsiveness to anti-PDGF antibody may result from the mediation of the early proliferative phase by other growth factors such as bFGF released from damaged mesangial cells. This assumption is supported by our finding that similar to observations in normal and injured vessels of bFGF-infused rats (6), injured mesangial cells (but not normal mesangial cells) were susceptible to bFGF-induced proliferation in vivo. The reason(s) for the increased responsiveness of injured mesangial cells to the mitogenic effects of bFGF remains unknown, although it has been suggested that upregulation of bFGF receptors after cellular injury may be involved (6). Alternatively, the accessibility of bFGF to mesangial cells in vivo may depend on the previous (subclinical) disruption of the normal extracellular matrix. However, this latter possibility is not supported by in vivo findings in vascular endothelial cells, which despite continuous exposure to injected, circulating bFGF were growth responsive towards bFGF only after injury (6). The observation that only injured mesangial cells in vivo appear to be growth responsive to bFGF is also consistent with the finding of a mitogenic effect of bFGF on cultured mesangial cells. Thus, mesangial cells in vitro have been shown to express $\alpha$-smooth muscle actin (40), to secrete predominantly interstitial types of collagen (41), and to proliferate even under serum-free conditions (42), and thereby exhibit various features characteristic of injured rather than normal mesangial cells in vivo (11-13).

In contrast to the potential involvement of bFGF in the initiation of mesangial cell proliferation during the early phase of anti-Thy 1.1 nephritis (days 1 and 2), our data do not support a role for bFGF in the later phases of mesangial cell proliferation (anti-Thy 1.1 nephritis days 4 and 6). Thus, as mentioned above, neither the induction of mesangial cell proliferation in vitro with cytokines such as PDGF nor the stimulation of the cells with various other cytokines resulted in a detectable bFGF release. These findings are consistent with the apparent absence of bFGF in the glomerular extracellular matrix during the peak of mesangial cell proliferation in the anti-Thy 1.1 model, and suggest that the marked increase in glomerular bFGF gene and protein expression during anti-Thy 1.1 nephritis reflects mainly a reconstitution of the physiologic mesangial cell content of bFGF. On the other hand, we can not exclude that transient cellular overproduction of bFGF may result in an autocrine mitogenic signal through hypothetical intracellular signaling pathways involving nuclear bFGF-receptors (43).

In conclusion, the present study provides the first evidence that glomerular mesangial cells in vivo are capable of synthesizing bFGF, that they may release bioactive bFGF in response to injury, and that bFGF is mitogenic for injured mesangial cells. Mesangiolysis, as an indication of mesangial injury, has been noted in a variety of human glomerular diseases (15). In the presence of constitutive mesangial bFGF expression, this study suggests that mesangial injury and subsequent release of bFGF may be an important mechanism involved in the onset of mesangial hyperplasia in man. Experimental $(13,23,44)$ as well as clinical (45) observations support the notion (46) that this onset of mesangial cell proliferation may be a critical predecessor for the development of mesangial matrix expansion and ultimately, glomerulosclerosis.

\section{Acknowledgments}

We thank Synergen (Boulder, $\mathrm{CO}$ ) for generously providing the bFGF; T. Reilly, DuPont-Merck (Wilmington, DE) for providing monoclonal anti-bFGF antibodies; and A. Baird and R. Florkiewicz, (La Jolla, CA) for providing the $\mathrm{bFGF} \mathrm{cDNA}$ and positive controls. 
This study was supported by U.S. Public Health Service grants DK39068, DK-43422, and HL-03174, by research grants provided by the Northwest Kidney Foundation, and by a postdoctoral stipend of the Deutsche Forschungsgemeinschaft to J. Floege.

\section{References}

1. Klagsbrun, M., and E. R. Edelman. 1989. Biological and biochemical properties of fibroblast growth factors. Implications for the pathogenesis of atherosclerosis. Arteriosclerosis. 9:269-278.

2. D'Amore, P. A. 1990. Modes of FGF release in vivo and in vitro. Cancer Metastasis Rev. 9:227-238.

3. Muthukrishnan, L., E. Warder, and P. L. McNeil. 1991. Basic fibroblast growth factor is efficiently released from a cytosolic storage site through plasma membrane disruptions of endothelial cells. J. Cell. Physiol. 148:1-6.

4. Baird, A., and N. Ling. 1987. Fibroblast growth factors are present in the extracellular matrix produced by endothelial cells in vitro: implication for a role of heparinase-like enzymes in the neovascular response. Biochem. Biophys. Res. Commun. 142:428-435.

5. Ishai-Michaeli, R., A. Eldor, and I. Vlodavsky. 1990. Heparanase activity expressed by platelets, neutrophils, and lymphoma cells releases active fibroblast growth factor from extracellular matrix. Cell Regul 1:833-842.

6. Lindner, V., R. A. Majack, and M. A. Reidy. 1990. Basic fibroblast growth factor stimulates endothelial regrowth and proliferation in denuded arteries. $J$. Clin. Invest. 85:2004-2008.

7. Lindner, V., and M. A. Reidy. 1991. Proliferation of smooth muscle cells after vascular injury is inhibited by an antibody against basic fibroblast growth factor. Proc. Natl. Acad. Sci. USA. 88:3739-3743.

8. Baird, A., F. Esch, P. Böhlen, N. Ling, and D. Gospodarowicz. 1985. Isolation and partial characterization of an endothelial cell growth factor from the bovine kidney: homology with basic fibroblast growth factor. Regul. Pep. 12:201213.

9. Silver, B. J., F. E. Jaffer, and H. E. Abboud. 1988. Platelet-derived growth factor synthesis in mesangial cells: induction by multiple peptide mitogens. Proc. Natl. Acad. Sci. USA. 86:1056-1060.

10. Yamamoto, T., and C. B. Wilson. 1987. Quantitative and qualitative studies of antibody-induced mesangial cell damage in the rat. Kidney Int. 32:514525.

11. Johnson, R. J., R. L. Garcia, P. Pritzl, and C. E. Alpers. 1990. Platelets mediate glomerular cell proliferation in immune complex nephritis induced by anti-mesangial cell antibodies in the rat. Am. J. Pathol. 136:369-374.

12. Johnson, R. J., H. Iida, C. E. Alpers, M. W. Majesky, S. M. Schwartz, P. Pritzl, K. Gordon, and A. M. Gown. 1991. Expression of smooth muscle cell phenotype by rat mesangial cells in immune complex nephritis. J. Clin. Invest. 87:847-858

13. Floege, J., R. J. Johnson, K. Gordon, H. lida, P. Pritzl, A. Yoshimura, C. Campbell, C. E. Alpers, and W. G. Couser. 1991. Increased synthesis of extracellular matrix in mesangial proliferative nephritis. Kidney Int. 40:477-488.

14. Iida, H., R. Seifert, C. E. Alpers, R. G. K. Gronwald, P. E. Phillips, P. Pritzl, K. Gordon, A. M. Gown, R. Ross, D. F. Bowen-Pope, and R. J. Johnson. 1991. Platelet-derived growth factor (PDGF) and PDGF receptor are induced in mesangial proliferative nephritis in the rat. Proc. Natl. Acad. Sci. USA. 88:65606564.

15. Morita, T., and J. Churg. 1983. Mesangiolysis. Kidney Int. 24:1-9.

16. Alpers, C. E., K. L. Hudkins, A. M. Gown, and R. J. Johnson. 1992.

Enhanced expression of "muscle-specific" actin in glomerulonephritis. Kidney Int. 41:1134-1142.

17. O’Donoghue, D. J., A. Darvill, and F. W. Ballardie. 1991. Mesangial cell autoantigens in immunoglobulin-A nephropathy and Henoch-Schönlein purpura. J. Clin. Invest. 88:1522-1530.

18. Reilly, T. M., D. S. Taylor, W. F. Herblin, M. J. Thoolen, A. T. Chiu, D. W. Watson, and P. B. M. W. M. Timmermans. 1989. Monoclonal antibodies directed against basic fibroblast growth factor which inhibit its biological activity in vitro and in vivo. Biochem. Biophys. Res. Commun. 2:736-743.

19. Adler, S., P. J. Baker, R. J. Johnson, R. F. Ochi, P. Pritzl, and W. G. Couser. 1986. Complement membrane attack complex stimulates production of reactive oxygen metabolites by cultured rat mesangial cells. J. Clin. Invest. 77:762-767.

20. Floege, J., N. Topley, J. Hoppe, T. B. Barrett, and K. Resch. 1991. Mitogenic effect of platelet-derived growth factor in human glomerular mesangial cells: modulation and/or suppression by inflammatory cytokines. Clin. Exp. Immunol. 86:334-341.

21. Schulze, M., P. J. Baker, D. T. Perkinson, R. J. Johnson, R. F. Ochi, R. A. K. Stahl, and W. G. Couser. 1989. Increased urinary excretion of C5b-9 distinguishes passive Heymann nephritis in the rat. Kidney Int. 35:60-68.

22. Johnson, R. J., W. G. Couser, E. Y. Chi, S. Adler, and S. J. Klebanoff. 1987. New mechanism for glomerular injury. Myeloperoxidase-hydrogen peroxide-halide system. J. Clin. Invest. 79:1379-1387.
23. Floege, J., M. W. Burns, C. E. Alpers, A. Yoshimura, P. Pritzl, K. Gordon, R. A. Seifert, D. F. Bowen-Pope, W. G. Couser, and R. J. Johnson. 1992. Glomerular cell proliferation and PDGF expression precedes glomerulosclerosis in the remnant kidney model. Kidney Int. 41:297-309.

24. Shimasaki, S., N. Emoto, A. Koba, M. Mercado, F. Shibata, K. Cooksey, A. Baird, and N. Ling. 1988. Complementary DNA cloning and sequencing of rat ovarian basic fibroblast growth factor and tissue distribution study of its mRNA. Biochem. Biophys. Res. Commun. 157:256-263.

25. Quarto, N., D. Talarico, A. Sommer, R. Florkiewicz, C. Basilico, and D. B. Rifkin. 1989. Transformation by basic fibroblast growth factor requires high levels of expression: comparison with transformation by hst/K-fgf. Oncogene Res. 5:101-110.

26. Thompson, R. W., G. F. Whalen, K. B. Saunders, T. Hores, and P. A. D'Amore. 1990. Heparin-mediated release of fibroblast growth factor-like activity into the circulation of rabbits. Growth Factors. 3:221-229.

27. Pabst, R., and R. B. Sterzel. 1983. Cell renewal of glomerular cell types in normal rats. An autoradiographic study. Kidney Int. 24:626-631.

28. Yayon, A., M. Klagsbrun, J. D. Esko, P. Leder, and D. M. Ornitz. 1991 Cell surface heparin-like molecules are required for binding of basic fibroblast growth factor to its high affinity receptor. Cell 64:841-848.

29. Rapraeger, A. C., A. Krufka, and B. B. Olwin. 1991. Requirement of heparan sulfate for bFGF-mediated fibroblast growth and myoblast differentiation. Science (Wash. DC). 252:1705-1708.

30. Klein, D. J., D. M. Brown, Y. Kim, and T. R. Oegema. 1990. Proteoglycans synthesized by human glomerular mesangial cells in culture. J. Biol. Chem. 265:9533-9543.

31. Florkiewicz, R. Z., and A. Sommer. 1989. Human basic fibroblast growth factor gene encodes four polypeptides: three initiate translation from non-AUG codons. Proc. Natl. Acad. Sci. USA. 86:3978-3981.

32. Abraham, J. A., A. Mergia, J. L. Whang, A. Tumolo, J. Friedman, K. A. Hjerrild, D. Gospodarowicz, and J. C. Fiddes. 1986. Nucleotide sequence of a bovine clone encoding the angiogenic protein, basic fibroblast growth factor. Science (Wash. DC). 233:545-548.

33. Hondermarck, H., J. Courty, B. Boilly, and D. Thomas. 1990. Distribution of intravenously administered acidic and basic fibroblast growth factors in the mouse. Experientia (Basel). 46:973-974.

34. Moscatelli, D. 1988. Metabolism of receptor-bound and matrix-bound basic fibroblast growth factor by bovine capillary endothelial cells. J. Cell Biol. 107:753-759.

35. Schweigerer, L., G. Neufeld, J. Friedman, J. A. Abraham, J. C. Fiddes, and D. Gospodarowicz. 1987. Capillary endothelial cells express basic fibroblast growth factor, a mitogen that stimulates their growth. Nature (Lond.). 325:257259.

36. Vlodavsky, I., R. Friedman, R. Sullivan, J. Sasse, and M. Klagsbrun. 1987. Aortic endothelial cells synthesize basic fibroblast growth factor which is secreted. J. Cell. Physiol. 131:402-428.

37. Baird, A., P. Mormede, and P. Böhlen. 1985. Immunoreactive fibroblast growth factor in cells of peritoneal exudate suggest its identity with macrophage derived growth factor. Biochem. Biophys. Res. Commun. 126:358-363.

38. Yoshimura, A., K. Gordon, C. E. Alpers, J. Floege, P. Pritzl, R. Ross, W. G. Couser, D. F. Bowen-Pope, and R. J. Johnson. 1991. Demonstration of PDGF B-chain mRNA in glomeruli in mesangial proliferative nephritis by in situ hybridization. Kidney Int. 40:470-476.

39. Johnson, R. J., E. Raines, J. Floege, A. Yoshimura, P. Pritzl, C. E. Alpers, and $R$. Ross. Inhibition of mesangial cell proliferation and matrix expansion in glomerulonephritis in the rat by antibody to platelet derived growth factor. $J$. Exp. Med. 175:1413-1416.

40. Drenckhahn, D., H. Schnittler, R. Nobiling, and W. Kriz. 1990. Ultrastructural organization of contractile proteins in rat glomerular mesangial cells. Am. J. Pathol. 137:1343-1351.

41. Haralson, M. A., H. R. Jacobson, and R. L. Hoover. 1987. Collagen polymorphism in cultured rat kidney mesangial cells. Lab. Invest. 57:513-523.

42. Floege, J., N. Topley, K. Wessel, V. Kaever, H. H. Radeke, J. Hoppe, T. Kishimoto, and K. Resch. 1990. Monokines and platelet derived growth factor modulate prostanoid production in growth arrested human mesangial cells. Kidney Int. 37:859-869.

43. Yayon, A., and M. Klagsbrunn. 1990. Autocrine regulation of cell growth and transformation by basic fibroblast growth factor. Cancer Metastasis Rev. 9:191-202.

44. Pesce, C. M., L. J. Striker, E. Peten, S. J. Elliot, and G. E. Striker. 1991. Glomerulosclerosis at both early and late stages is associated with increased cell turnover in mice transgenic for growth hormone. Lab. Invest. 65:601-605.

45. Fogo, A., E. P. Hawkins, P. L. Berry, A. D. Glick, M. L. Chiang, R. C. MacDonell, and I. Ichikawa. 1990. Glomerular hypertrophy in minimal change disease predicts subsequent progression to focal glomerular sclerosis. Kidney Int. 38:115-123.

46. Striker, L. J., E. P. Peten, S. J. Elliot, T. Doi, and G. E. Striker. 1991 Mesangial cell turnover: effect of heparin and peptide growth factors. Lab. Invest. 64:446-456. 